\title{
Exercise of human rights of institutionalized persons: perception of psychiatric hospital professionals
}

\author{
Exercício dos direitos humanos de pessoas institucionalizadas: percepção de profissionais de hospital psiquiátrico
}

Ejercicio de los derechos humanos de personas institucionalizadas: percepción de profesionales de hospital psiquiátrico

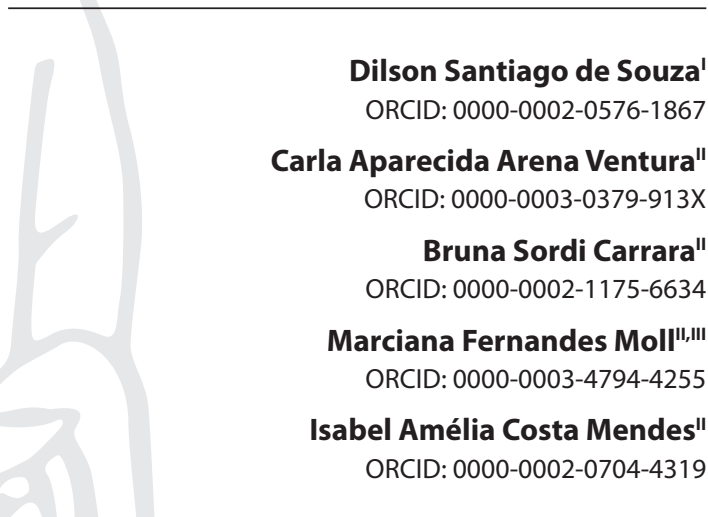

'Centro Universitário de Franca. Franca, São Paulo, Brazil. "Universidade de São Paulo, Escola de Enfermagem de Ribeirão

Preto. Ribeirão Preto, Brazil.

"'Universidade de Uberaba. Uberaba, Minas Gerais, Brazil.

How to cite this article:

Souza DS, Ventura CAA, Carrara BS, Moll MF,

Mendes IAC. Exercise of human rights of institutionalized persons: perception of psychiatric hospital professionals. Rev Bras Enferm. 2020;73(1):e20180519. doi: http://dx.doi.org/10.1590/0034-7167-2018-0519

Corresponding Author:

Carla Aparecida Arena Ventura

E-mail: caaventu@eerp.usp.br

EDITOR IN CHIEF: Antonio José de Almeida Filho ASSOCIATE EDITOR: Fátima Espírito Santo

Submission: 06-16-2018 Approval: 05-02-2019

\begin{abstract}
Objective: to comprehend the existing possibilities for the exercise of human rights by persons with mental disorders who are institutionalized in a psychiatric hospital, from the perception of professionals. Method: this is a qualitative descriptive-exploratory study conducted at a Psychiatric Hospital in the state of São Paulo, Brazil. For data obtention, eleven professionals responded to a semistructured questionnaire. The traditional content analysis proposed by Bardin based the data analysis. Results: the professionals know the human rights and try to preserve them in the hospital scope, although they recognize that the persons hospitalized are not entirely respected due to the lack of public policies or their non-suitability to the Brazilian reality. Final considerations: the structuring of extrahospital services is necessary, as well as the comprehension of the professionals that act in psychiatric hospitals about the objectives and the functioning of such devices to assure opportunities of exercising rights by institutionalized persons.

Descriptors: Human Rights; Hospitalization; Psychiatry; Institutionalization; Mental Health
\end{abstract}

\section{RESUMO}

Objetivo: compreender as possibilidades existentes para o exercício dos direitos humanos por pessoas com transtornos mentais institucionalizadas em um hospital psiquiátrico, com base na percepção dos profissionais. Método: estudo descritivo-exploratório, qualitativo, realizado em um hospital psiquiátrico do interior de São Paulo. Para a obtenção dos dados, 11 profissionais responderam a um questionário semiestruturado. A análise de conteúdo tradicional, proposta por Bardin, fundamentou a análise dos dados. Resultados: os profissionais conhecem os direitos humanos e tentam preservá-los no âmbito hospitalar, embora reconheçam que as pessoas hospitalizadas não são totalmente respeitadas, em razão da falta ou inadequação de políticas públicas à realidade brasileira. Considerações finais: faz-se necessária a estruturação de serviços extra-hospitalares, além de maior compreensão dos profissionais atuantes nos hospitais psiquiátricos sobre os objetivos e o funcionamento desses dispositivos, a fim de assegurar oportunidades para que pessoas institucionalizadas exerçam seus direitos.

Descritores: Direitos Humanos; Hospitalização; Psiquiatria; Institucionalização; Saúde Mental.

\section{RESUMEN}

Objetivo: comprender las posibilidades para el ejercício de los derechos humanos por personas con trastornos mentales institucionalizadas en un hospital psiquiátrico, a partir de la percepción de los profesionales. Método: estudio descriptivo-exploratório cualitativo, realizado en un Hospital Psiquiátrico del interior de São Paulo. Para la recolección de datos, once profesionales respondieron a un cuestionário semiestructurado. El análisis de contenido tradicional, propuesto por Bardin, embasó el análisis de datos. Resultados: los profesionales conocen los derechos humanos y buscan su ejercício en el ámbito hospitalário, además de reconoceren que las personas hospitalizadas no son totalmente respetadas, en razón de la falta de políticas públicas o de su no adecuación a la realidad brasileña. Consideraciones finales: es necesária la estructuración de los servicios extra hospitalares y la comprensión de los profesionales que están en los hospitales psiquiátricos sobre los objetivos y el funcionamento de estes dispositivos para asegurar oportunidades de ejercício de derechos por personas institucionalizadas.

Descriptores: Derechos Humanos; Hospitalización; Psiquiatria; Institucionalización; Salud Mental. 


\section{INTRODUCTION}

In a world context, the respect, promotion, and guarantee of rights of persons with mental disorders represent challenges since the violation of fundamental human rights of such persons occurs inclusively in mental health services ${ }^{(1)}$. Added to this reality are the violation and denial of the right to freedom of such persons, as a result of discrimination, stigmatization, marginalization, and exclusion processes to which they are submitted in the scope of some specialized health services ${ }^{(2)}$.

This reality drove the Psychiatric Reform movement, which resulted from the fight for ensuring the human rights of persons with mental disorders and aims to provide social inclusion, without discrimination and segregation, which requires affirmative actions by the State ${ }^{(3)}$. In Brazil, this movement gained strength from the 1980s, culminating with Law no. 10216 of 2001, which reorganizes the psychiatric assistance model through a network of community-based actions and public health services and prioritizes social reinsertion ${ }^{(4)}$.

This legislation also establishes that psychiatric hospital admission must occur when the interventions in community services are insufficient for the treatment. In the face of long-term hospitalizations, one must value the deinstitutionalization process, which requires planning for the discharge and assisted psychosocial rehabilitation, assuring the continuity of the treatment ${ }^{(4)}$.

However, deinstitutionalization must extend to the community scope and, for this purpose, it is fundamental that the community offer support and a favorable environment so that persons with mental disorders may exert their human rights ${ }^{(5)}$. Human rights are essential for persons to have dignity and quality in their lives. They include the following rights: to life, to freedom, to work, to education, to health, and to housing, among others. All persons deserve to exert such rights, without privileges or discrimination. Human rights must be respected unconditionally, especially in the case of persons with mental disorders ${ }^{(6)}$.

Even in the face of such legal initiatives and of a Psychiatric Reform movement which seeks to provide care based on human dignity, psychiatric hospitals continue exerting the protagonism in providing psychiatric care for being considered by many professionals and members of the society as the most appropriate environment for care and even permanence of persons with mental disorders ${ }^{(7)}$.

From this reality, there are persons with mental disorders institutionalized in psychiatric hospitals, which represents a delicate and complex issue that demands interdisciplinary and intersectoral analysis under the prism of the principle of dignity of the human person. For this purpose, it is first essential to comprehend mental disorders as multidetermined processes that consider, in the psychosocial rehabilitation necessary for exercising citizenship, the influence of the context in which the subject is inserted, and the persons with whom they live ${ }^{(8)}$. In this context, deinstitutionalization represents a crucial stage.

In this sense, citizenship was definitely incorporated to the Brazilian national justice ordering through the Federal Constitution of 1988 which, already in its first article, defines the Federative Republic of Brazil as a Democratic State of Right and, non-exhaustively, establishes the fundaments which support the
State: sovereignty, citizenship, dignity of the human person, social values of work and of initiative, as well as political pluralism ${ }^{(9)}$.

Specifically, the third article of the Brazilian Federal Constitution establishes the following as fundamental objectives of the Federative Republic of Brazil: to build a free, just, and supportive society, guarantee national development, eradicate poverty and marginalization, reduce the social and regional inequalities, and promote the wellness of all, without prejudice of origin, race, gender, color, age, or any other forms of discrimination ${ }^{(10)}$.

In this historical context of affirmation of human rights, the issue of the existence of persons with mental disorders who are institutionalized in Brazil persists, not having been resolved with the advance of the legal guidelines of mental health. For this reason, it is believed that it is essential to invest in scientific works that enable the critical reflection of this process.

\section{OBJECTIVE}

To comprehend the existing possibilities for the exercise of human rights by persons with mental disorders who are institutionalized in a psychiatric hospital of a city in the state of São Paulo, Brazil, from the perceptions of the professionals.

\section{METHOD}

\section{Ethical aspects}

We began the investigation after the approval of the Research Ethics Committee of the University Center of Franca (Uni-FACEF), followed by the clarification, for all participants, of the objectives of the research and the signature of the Free and Informed Consent Form. To assure their anonymity, the participants were identified by the first letter of the professional category to which they belong and by sequential participation numbers for each category.

\section{Type of study}

This study is characterized as descriptive-exploratory with a qualitative approach.

\section{Study scenario}

We conducted the investigation in a city with approximately 340 thousand inhabitants in the state of São Paulo, Brazil.

The Psychiatric Hospital that constitutes the investigation scenario is destined for the service of persons with acute severe mental disorders, in need of intensive treatment and symptom stabilization. It is a philanthropic institution in covenant with the Unified Health System (UHS) for caring for up to two hundred users at least eighteen years old and who reside in the coverage area of the Regional Health Department (RHD) III ${ }^{(10)}$.

The professional team is composed of six psychiatrists of reference, seven psychiatrists on duty, three general practitioners, neurologist, gynecologist, eight nurses, four psychologists, three social workers, three occupational therapists, two physical educators, nutritionist, physical therapist, pharmacist, five workshop instructors, 108 nursing technicians and assistants, as well as 74 general service assistants (cleaning and kitchen). Regarding 
the care offered, medication treatment and individual, in-group, and with-family services are present, as well as therapeutic tours destined for users that live in the hospital.

The flow for servicing the users that reside in the municipality occurs ordinarily through the Vacancy Regulation Central, actuated from a referral by the psychiatric ward of the Municipal Emergency Room. Regarding the demand met by the Hospital, although there is an estimate of the offer of two hundred beds for the stabilization of acute severe mental disorders, at the moment of data collection, most of such beds were occupied by users institutionalized in the service (resident-users-96), while another significant parcel was unavailable due to the permanence in the hospital of users admitted by judicial determination (17) or that had been medically discharged (87) but did not count on family and community backing for life in society.

\section{Study participants}

Eleven professionals of the mentioned institution participated in the investigation, and the interruption of data collection met the saturation criterion, according to which the inclusion of new participants is suspended when there occurs the repetition of information ${ }^{(11)}$.

We used as inclusion criteria those professionals who were employees of the institution for at least two years (due to the importance of the participants knowing the institution well and having had some experience with the persons institutionalized, even after the discharge) and accepted to participate in the research by signing the Free and Informed Consent Form (FICF). We excluded those who were away from work activities for health or maternity leave.

\section{Data collection and organization}

The data were collected through a semistructured instrument elaborated by the researchers based on the literature review and considering the study objectives. In the instrument, we initially addressed aspects that allowed tracing an overall profile of the participants (professional category, gender, marital status, time of professional training, and bond time with the Institution). Then, the questionings sought to recognize the exercise of the rights of the institutionalized persons with mental disorders and the strategies for integration into society.

\section{Data analysis}

For data analysis, we employed the thematic content analy$\operatorname{sis}^{(12)}$. First, the answers of each representative were analyzed. In sequence, we listed the points of similarity and difference among the contents, as well as whatever may be highlighted as relevant to achieve the research objectives. The results were gathered into categories, discussed based on the literature review on the theme ${ }^{(12)}$.

\section{RESULTS}

Three physicians, two social workers, two psychologists, two nurses, one physical educator, and one middle-level professional of the administrative area of the Psychiatric Hospital participated in the study.
Among these professionals, six are women and five are men, ten are married and one is single, and ten concluded their university education more than fifteen years before and one graduated four years prior. Regarding the time for which the professionals worked at the Institution, the average is of 12.3 years, demonstrating the existence of a long-term bond with the Hospital.

The exercise of human rights by persons institutionalized in psychiatric hospitals was analyzed from the emerging categories and subcategories of this study.

\section{Category 1: The exercise of human rights and the psychi- atric institutionalization}

The exercise of human rights by institutionalized persons with mental disorders was grasped in two subcategories.

\section{Knowledge and practices of the professionals in the face of the rights of institutionalized persons with mental disorders}

When questioned about the exercise of rights of persons with mental disorders, the professionals demonstrated knowing what these rights are, basing themselves on the fundamental rights of the human being:

[...] to receive a humanized treatment and, in society, be respected by their family, relatives, society, and government. (EF1)

[...] to have access to the best treatment of the health system; treatment with humanity and respect; to receive information referring to their disease; protection against any form of prejudice. (E1)

[...] complete attention to health, attention by social care, to be welcomed into the family. (M1)

[...] treatment with humanity and respect, protection against any form of abuse and exploitation, receive information about their disease [disorder] and treatment, be treated in a therapeutic environment. (P1)

Regarding the respect of the fundamental human rights of the institutionalized persons, the answers were brief but pointed to unanimity of the fact that they are not entirely respected:

Partially. (AS2)

Yes and no. (A1)

Not entirely. (M1)

Only part of them. (P2)

Nor of the bearers nor the others. (M3)

Currently, these rights are not respected. (M2)

However, some agree with the attempt to preserve human rights in the best way possible within the institution:

In respect to the care provided to the patients in this institution, we count on a capacitated and acting team aiming the best care 
to the clients; however, it is known that the population that suffers from some mental disorder is still socially excluded. We still have much to evolve. (E1)

They are respected when they are accommodated into institutions, into earnest and specialized institutions. They are not respected when they are tossed on the streets, in prisons, due to an equivocated mental health policy promoted by the Ministry of Health, with the closure of hospital beds. (A1)

Given the exposed, it is made evident that the professionals recognize the fundamental human rights but consider that they are not entirely respected during the admissions of institutionalized persons, even with the attempt of preserving them in the scope of the psychiatric hospital.

\section{Public policies and the rights of institutionalized persons with mental disorders}

The participants reported that the lack of public policies or their non-suitability for the Brazilian reality justifies the gaps in the exercise of rights of these persons that remain hospitalized:

Due to the lack of structures within the public policy. (P1)

The mental health policy in Brazil, in theory, is quite rich but lacks adequacy to our current reality for a successful practice. (P2)

They also consider that there exist faults in the public system that compromises the compliance with the legislation in place, such as expressed in the following accounts:

Federal Law 10256 disposes about the protection and the rights of people bearers of mental disorders; however, we know that the process still shows faults in its execution. (E1)

[...] due to the lack of resources in the UHS and overload of the judiciary system. (M2)

Due to the existing faults in the public system. They do not commit to enforcing the few already existing laws. (AS2)

It is noticeable that the difficulties in integrating human rights during psychiatric hospitalization seem to result from the lack or unsuitability of the public policies and from faults in the public system for meeting the legislation in place, which also interferes with the integration of the person with a mental disorder into society.

\section{Category 2: Impasses for the deinstitutionalization and real possibility of exercising human rights}

The impasses for the deinstitutionalization and real possibility of exercising human rights were consolidated in three subcategories.

\section{Lack of welcoming by the family and society}

Among the main impasses for deinstitutionalization, the rejection of people with mental disorders by their families and the general society stood out:
The family rejects the patient because they end of getting as sick as the patient, who is rejected by society because the mentally ill are rejected. $(\mathrm{EF} 1)$

The lack of family and social welcoming causes the person to remain hospitalized until they have conditions of going back into societal conviviality and, for this, the family must be able to receive them

However, the family does not always feel prepared for this welcoming:

Even though the patient improves and is discharged, the family does not always take them home alleging unpreparedness. (M2)

Through the collected data, it was noticed that the professionals point out family and societal rejection as the main impasses for the deinstitutionalization and, consequently, for the access to fundamental rights such as freedom.

\section{Strategies proposed for the integration of persons with mental disorders into society}

For the participants in this investigation, the possibilities for overcoming the impasses mentioned above for the deinstitutionalization and consequent exercise of human rights by such people center primarily on the creation and development of public policies aiming to service the population with mental disorders.

Nonetheless, they emphasized the need to get to know the reality of the city to propose policies that are coherent with such situation.

Firstly get to know better the needs and reality of the health care conditions to be provided to the patients. (E1)

To get to know better the reality of this area and then create and monitor projects and, along with the community, charge from the public policies in the three spheres, namely Municipality, State, and Federal. (AS1)

The financial issue was also mentioned, suggesting the increase of federal transfers and of the values established on the UHS table to pay the institutions for the health services provided to this population, which would enable the improvement of the quality of such services.

[...] increase the transfers and raise the UHS table for the services, consequently, the hospitals will be able to offer better treatment conditions. (EF1)

Also cited was the need for more significant interaction between public managers and the society for the implantation of better mental health services in the cities.

Treatment continuity together with earnest institutions, with specialized teams, and in specific wards, so that this patient "rejected" by their family and society and who requires follow-up is duly serviced and welcomed. (A1)

[...] social revolution at several levels. (M3) 
Considering the reports of the participants, it is noticeable that the principle of decentralization of health is not valued upon elaborating public policies, given that one does not ponder the local reality nor update the tables of financial transference for the services provided, generating a lack or insufficiency of public services.

\section{Reflecting on the Therapeutic Residential Service as a dein- stitutionalization device}

Upon addressing the existence of the proposal of the Therapeutic Residential Service (TRS), nine participants stated they already know it, and two alleged ignoring its existence. Among those who knew about it, there were reports of how the program works and that its implementation in the city would be valuable.

\section{[...] in our region, it practically doesn't exist. (M1)}

[...] it would be important to expand this service in our area. (M2)

Regarding the de-hospitalization policy, the difficulty of implanting the TRS was also questioned.

[...] I see a need for more commitment by public policies for the concretization of this project more comprehensively in our country. (AS2)

[...] there is a lack of political interest and of preparation of the teams to increment the program. (M1)

[...] a program that presents little results, unsatisfactory at the moment in the face of the reality of our country. (AS1)

[...] a program from the federal government that to date has not been able to achieve its objectives. (A1)

Overall, it is made evident that the professionals do not have concrete experience in the face of the proposal instituted in the TRS, which causes them to have a restricted view about the contributions of this service to de-hospitalization, deinstitutionalization, and how it would favor the exercise of human rights of people that remain hospitalized even after being medically discharged.

\section{DISCUSSION}

Upon analyzing the reality identified in this investigation about the perception of professionals regarding the institutionalized persons with mental disorders and the exercise of their human rights, we came across a positive framework of knowledge of the participants concerning fundamental rights. This finding corroborates with the study ${ }^{(3)}$ conducted at a Psychosocial Care Center (PCC) with the objective of describing the perception of professionals about the human rights of the mentally ill and the means for the realization of such rights during health care. The professionals presented understandings about the human rights related to the right to freedom, to the exercise of autonomy and the protection of the life of such persons, and listed the importance of the rights of persons with mental disorders as a basis for their coexistence in society, ensuring the exercise of their citizenship.
In this study, when responding about the knowledge of the rights of persons with mental disorders, the professionals emphasized rights related to humanized care (right to health), corroborating what is assured in the second principle of the Health Users' Rights Letter, such as the adequate and effective treatment for their problem, aiming at improving the quality of the services offered ${ }^{(13)}$. The single paragraph of the second article of Law 10216 establishes that the person with a mental disorder must have access to care, preferentially communal, that is dignified and humanized, centered on the integrality and on human rights, which demands protection, humanization, respect, and social and familial inclusion ${ }^{(14)}$.

However, in this investigation, it was pointed out that the respect to the human rights of persons with mental disorders is not integrally valued, although there is an attempt to preserve them within the institution. This situation interferes directly on the exercise of citizenship and the basic principles of the Psychiatric Reform given that, in a recent study ${ }^{(3)}$, it was verified that in the scope of health, especially mental health, one must prioritize the assurance of the human rights of persons with mental disorders, aiming at social inclusion, without discrimination and segregation, housed by affirmative actions by the State.

We emphasize that the psychiatric hospital-centered model produces significant losses in the lives of persons with mental disorders, omitting broad and structural social aspects, as well as psychosocial ones such as the familial and social relations, which are indissociable from the life of the individual and that interfere in their process of health and mental suffering ${ }^{(15)}$. Besides, the losses stemming from a psychic sickening and psychiatric internment are countless and may be represented by harm in the professional, emotional, and cultural relations that interfere adversely in the exercise of human rights ${ }^{(16)}$.

From this reality, the deinstitutionalization policy in Brazil has been characterized by the reduction of beds in psychiatric hospitals and the implantation of a network of integrated devices that intend to replace the model centered on the psychiatric hospital ${ }^{(17)}$. However, the participants in this investigation report that the lack or unsuitability of public policies interferes in the caring of persons institutionalized in psychiatric hospitals. This corresponds to a critique of the deinstitutionalization process, which, according to them, does not offer support for the realization of this new policy of mental health care. This discourse has representativity due to the argument that points out that the closing o psychiatric beds without the implantation of public care services and the practical social support may cause abandonment and neglect due to the difficulties that persons in deinstitutionalization processes have in maintaining themselves autonomously in the society ${ }^{(8)}$.

The present study professionals reported the existence of flaws in the public system, emphasizing that the laws are not put into practice. It is understood that the existence of the legislation does not solve the problems faced, but represents a tool that enables reaching the objectives proposed. There is a need that mental health workers adopt the new model and incorporate it into their practices, rebuilding the traditional knowledge and seeking alternatives to realize the actions that respond to this new reality ${ }^{(18)}$. In other words, the new model will only be effective when mental health workers adopt it in partnership with the users and their families. 
Among the findings of this investigation, it stood out that the lack or unsuitability of public policies, as well as the flaws in the public system, interfere in the assistance based on the exercise of human rights and, consequently, on the integration into society of persons with mental disorders. A study ${ }^{(19)}$ points out that, since the beginning of the 21st century, psychiatric care must value the psychosocial context of persons with mental disorders and prioritize the involvement of the family in the treatment, which assumes the role of protagonist in the care. In this sense, our results make evident that there is still a rejection by the population and the families in the face of persons with mental disorders. The same was demonstrated in another study ${ }^{(3)}$ in which professionals stated that many families are not prepared to deal with family members with mental disorders due to the lack of support, which much hampers the evolution of the treatment. Besides, they argue that raising awareness and informing persons with mental disorders and their family members about their rights, as well as the general population, constitutes an effective means to materializing human rights.

The real difficulty of the relationship of the family with their members with mental disorders motivates the reflection that, when there is a refusal to take their family member home, it is because they were already abandoned by the State, by the lack of welfare programs that ensure them of their rights ${ }^{(20)}$. Given the relevance of the new role of families in the current segments of the Mental Health Policy, there is a need to discuss the action of the State in the face of such changes, considering that it is directed to the public power the provision of protection and support to the families and persons with mental disorders in this new model(21).

For this new model to materialize and the issue of social and familial rejection be overcome, the participants suggest that public policies be created observing the human rights of persons with mental disorders, according to the reality of the cities. In the face of this affirmative, we emphasize that the movement of decentralization of public policies encompasses public health in general from the creation of the UHS, with its directives of universality, equity, and integrality. Therefore, the primary challenge occurs between the creation of federal public policies and their implementation in cities, given that the effective functioning of such services concerns the administrative reality of each municipality ${ }^{(22)}$. De-hospitalization as a policy instituted by mental health services must consider both the subjective aspects of persons with mental disorders and the social and cultural universe in which they find themselves. In case this care does not exist, the health practices will possibly engender mechanisms that veto the exercise of the rights of persons with mental disorders. In this context, it is verified a continuous decline in the beds of psychiatric hospitals in Brazil and the progressive expansion of the PCCs ${ }^{(23)}$. However, one does not observe significant implantation of beds in general hospitals for the crises or the creation of residential long-permanence devices ${ }^{(24)}$.

In the discourse of the present study professionals, it became evident the need of more significant interaction among public and municipal managers and even the society for there to occur the qualification of the implementation of mental health services. This finding points to the challenge that persists and affects the production of mental health both regarding the users of the services and the workers. The more extensive the knowledge, acceptance, participation, and interaction of the manager with the proposals of the Psychiatric Reform, the higher the involvement and the possibility of advancing in the implementation of the mental health policy in the cities ${ }^{(25)}$.

From the different demands of mental health and considering the need for providing intersectoral care, in December of 2011, the Psychosocial Care Network (PCN) was regulated from Ordinance no. 3088 in the scope of the UHS, presenting, among its objectives, the promotion of the access of persons with mental disorders and with needs stemming from the use of psychoactive substances and their families to the care services to the biopsychosocial needs of this clientele ${ }^{(17)}$. It is emphasized, in this scenario, that the TRS is an attention point of the deinstitutionalization strategy component and the wide diffusion of this Network in the mental health services themselves justified the fact that the participants know about the TRS and identify it as a facilitator device of de-hospitalization.

The TRSs constitute housings in the community destined to persons with mental disorders who do not have family ties or social support. Such accommodations are occupied, mostly, by people that are egresses of long-term psychiatric internments (two or more consecutive years). To legally subsidize this proposal, Ordinance 106/2000, which regulates the creation of such housings in the scope of the UHS, and Ordinance 1220/2000, which regulates the functioning of such services ${ }^{(26)}$ stand out.

Even though legislations exist regulating from the creation to the functioning of the TRS, the participants of this investigation pointed out that there is a political disinterest for this device, which may be related to the fact that it represents a space of "housing" and not a place of treatment, as described in the scientific midst ${ }^{(27)}$. This reality caused its implantation to be postponed given that it was a priority to compose the extra-hospital treatment network to ensure de-hospitalization.

We also emphasize that it was pointed out by the participants that the TRS is little resolutive. Nevertheless, it is essential to review this statement. A recent study considers that such services exert a significant role in the construction of the lives of their residents in society ${ }^{(27)}$ because their central issue is to inhabit a house, aiming to compose the social network of their residents through their insertion into the web of health services and in communal relations ${ }^{(28)}$. In this sense, upon exiting isolation and starting to enjoy extra-hospital therapeutic assistance, persons with mental disorders have the potential to transform themselves into subjects of rights and of fact ${ }^{(29)}$.

Therefore, it is noticeable a need for professionals involved with mental health to be aware that the new assistance model is a continuous process that represents the possibility of exercising citizenship ${ }^{(25)}$. In this new proposal, therapeutic residency represents a device that leverages the (re)construction of the exercise of human rights among people that remained hospitalized for extended periods ${ }^{(30)}$.

Overall, the results point out a need for valuing the reality of the city to implement the existing policies, which seems pertinent due to the demand for the implementation of devices in the social means that deinstitutionalize persons with mental disorders. 


\section{Study limitations}

The study presents the reality of a single psychiatric hospital and the view of its professionals. It is also vital for a better understanding of this reality to involve in future studies the persons with mental disorders that are hospitalized in such services. Also, seeking to understand the current stage of implementation of public policies of the mental health field, the performance of studies with decision makers may bring other variables that contribute to the implementation of the extra-hospital model established in the current legislation.

\section{Contributions for the fields of nursing, health, or public policy}

The results of this study reflect the difficult implementation of extra-hospital services such as therapeutic residential services, which exert social and therapeutic roles in a country that presents relevant economic and social iniquities. It is verified that the legislation that creates the Therapeutic Residential Services was regulated in 2001, but the structuring of this service in the Brazilian territory is still small in the face of the demand of persons with mental disorders that remain institutionalized in psychiatric hospitals and, consequently, without exercising their fundamental rights. Thus, it is necessary that Therapeutic Residences are created that enable their residents to seek the exercise of some fundamental rights such as housing, leisure, freedom, and others.
Therefore, it is fundamental that mental health care is anchored on human rights and the principles of humanization of care for there not to occur a false deinstitutionalization. Among health professionals, nurses can and should exercise their political role through health advocacy, leading and contributing in their sphere of activity for the implementation of such services, facilitating the occurrence of gradual changes that aim the real application of the principles of the psychiatric reform of the country.

\section{FINAL CONSIDERATIONS}

The institutionalization in psychiatric hospitals limits the exercise of human rights of persons with mental disorders, among them the rights to freedom, health, work, housing, and education. In the present study, persons with mental disorders institutionalized in a psychiatric hospital are assisted by professionals that know the human rights and try to preserve them in the hospital scope. However, respect for their rights is not a real practice before such persons, which, for the participants, is aggravated in the social mean since society rejects them and their families are unprepared to welcome them.

Considering the relevance of this reality, it is fundamental that extra-hospital services are structured and organized for persons with mental disorders. It is also essential that professionals acting in psychiatric hospitals understand the functioning dynamics and the objectives of services such as therapeutic residences, which can welcome, protect, and contribute for the social reinsertion of persons with mental disorders who have been hospitalized for periods equal or longer than two years.

\section{REFERENCES}

1. Drew N, Funk M, Tang S, Lamichhane J, Chávez E, Katontoka S, et al. Human rights violations of people with mental and psychosocial disabilities: an unresolved global crisis. Lancet. 2011;378(9803):1664-75. doi: 10.1016/S0140-6736(11)61458-X

2. Braga CP. A qualidade e o respeito aos direitos humanos em serviços de saúde mental infantojuvenis: temas para avaliação e para construção de uma cultura de defesa de direitos [dissertação] [Internet]. Lisboa: Universidade NOVA de Lisboa; 2018 [cited 2018 Aug 10]. Available from: https://run.unl.pt/bitstream/10362/39624/1/Braga\%20Cl\%c3\%a1udia\%20TM\%202018.pdf

3. Ventura CAA, Moraes VCO, Jorge MS. Human rights of people with mental disorders: health professionals' and clients' views. Rev Enferm UERJ. 2016;25:e4344. doi: 10.12957/reuerj.2017.4344

4. Ministério da Saúde (BR). Secretaria de Atenção à Saúde, Departamento de Ações Programáticas Estratégicas, Coordenação Geral de Saúde Mental, Álcool e Outras Drogas. Saúde mental em dados - 8 [Internet]. Brasília: Ministério da Saúde; 2011 [cited 2018 Mar 15]. Available from: http://bvsms.saude.gov.br/bvs/periodicos/saude_mental_dados_v8.pdf

5. Abramenko L, Lovisi GM, Fonseca DL, Abelha L. Atitudes dos trabalhadores de saúde mental em relação aos pacientes psiquiátricos em uma cidade do interior do Estado do Rio de Janeiro. Cad Saúde Colet. 2017;25(2):169-76. doi: 10.1590/1414-462×2017000200019

6. Ventura CAA, Brito ES. Pessoas portadoras de transtornos mentais e o exercício de seus direitos [Internet]. Rev Rene. 2012 [cited 2018 Aug 15];13(4):744-54. Available from: http://www.periodicos.ufc.br/rene/article/view/4025

7. World Health Organization (WHO). Mental health, human rights and standards of care (2018) [Internet]. Geneva: WHO; 2018 [cited 2018 Aug 10]. Available from: http://www.euro.who.int/en/publications/abstracts/mental-health,-human-rights-and-standards-of-care-2018

8. Braga NG, Fernandes NFC, Rocha THR. A família no acompanhamento de sujeitos psicóticos: os encargos subjetivos oriundos do sofrimento psíquico. Aletheia [Internet]. 2014 [cited 2018 Feb 25]; (43-44):227-38. Available from: http://pepsic.bvsalud.org/scielo. php?script=sci_arttext\&pid=S1413-03942014000100017\&lng=pt\&nrm=iso\&tlng=pt

9. Senado Federal (BR). Constituição da República Federativa do Brasil: texto constitucional promulgado em 5 de outubro de 1988 , com as alterações determinadas pelas Emendas Constitucionais de Revisão nos 1 a 6/94, pelas Emendas Constitucionais nos 1/92 a 91/2016 e pelo Decreto Legislativo no 186/2008 [Internet]. Brasília: Senado Federal; 1988 [cited 2018 Mar 05]. Available from: https://www2.senado.leg.br/ bdsf/bitstream/handle/id/518231/CF88_Livro_EC91_2016.pdf 
10. São Paulo (Estado). Secretaria de Estado da Saúde (SES). Regionais de Saúde [Internet]. São Paulo: SES; 2012 [cited 2018 Jan 15]. Available from: http://www.saude.sp.gov.br/ses/institucional/departamentos-regionais-de-saude/regionais-de-saude

11. Fontanela BJB, Ricas J, Turato ER. Amostragem por saturação em pesquisas qualitativas em saúde: contribuições teóricas. Cad Saúde Pública. 2008;24(1):17-27. doi: 10.1590/S0102-311X2008000100003

12. Bardin L. Análise de Conteúdo. Lisboa: Edições 70; 2016.

13. Ministério da Saúde (BR). Carta dos direitos dos usuários da saúde [Internet]. Brasília: Ministério da Saúde; 2006 [cited 2018 Feb 21]. Available from: http://portalms.saude.gov.br/sistema-unico-de-saude/carta-dos-direitos-do-usuario

14. Ministério da Saúde (BR). Lei no 10.216, de 9 de abril de 2001. Dispõe sobre a proteção e os direitos das pessoas portadoras de transtornos mentais e redireciona o modelo assistencial em saúde mental [Internet]. Diário Oficial da União. 2001 Apr 9. Brasília; 2001 [cited 2018 Dec 15]. Available from: http://www.planalto.gov.br/ccivil_03/leis/leis_2001//10216.htm

15. Leão A, Barros S. Social inclusion and exclusion: the social representations of mental health professionals. Interface (Botucatu). 2012;15(36):137-52. doi: 10.1590/S1414-32832011000100011

16. Brunello MRI. Loucura um processo de desconstrução da existência. Rev Terapia Ocup USP. 1998;9(1):14-9.

17. Ministério da Saúde (BR). Gabinete do Ministro. Portaria GM n 3.088, de 23 de dezembro de 2011. Institui a Rede de Atenção Psicossocial para pessoas com sofrimento ou transtorno mental e com necessidades decorrentes do uso de crack, álcool e outras drogas, no âmbito do Sistema Único de Saúde (SUS) [Internet]. Brasília: Ministério da Saúde; 2011 [cited 2018 Jan 28]. Available from: http://bvsms.saude.gov.br/ bvs/saudelegis/gm/2011/prt3088_23_12_2011_rep.html

18. Moll MF, Silva LD, Magalhães FHL, Ventura CAA. Nursing professionals and psychiatric admission in general hospital: perceptions and professional training. Cogitare Enferm. 2017;(22)2:e49933. doi: 10.5380/ce.v22i2

19. Martinhago F, Oliveira WF. (De)institutionalization: the perception of Psychosocial Care Enter professionals in Santa Catarina, Brazil. Saúde Soc. 2015;24(4):1273-84. doi: 10.1590/S0104-12902015136741

20. Frazatto CF, Boarin ML. The "residence" in psychiatric hospital: stories told by families of ex-"residents". Psicol Estud. 2013;18(2):257-67. doi: $10.1590 /$ S1413-73722013000200007

21. Silva EKB, Rosa LCS. Desinstitucionalização Psiquiátrica no Brasil: riscos de desresponsabilização do Estado? Rev Katálysis. 2014;17(2):252-60. doi: 10.1590/S1414-49802014000200011

22. Pontes S, Lopes L, Santos LMM, Calazans R. Implantation of public policies in mental health: the case of São João del Rei [Internet]. Gerais: Rev Interinst Psicol. 2014 [cited 2018 Mar 21];7(2):260-8. Available from: http://pepsic.bvsalud.org/scielo. php?script=sci_abstract\&pid=S1983-82202014000200013\&lng=pt\&nrm=iso\&tlng=en

23. Amarante P, Nunes MO. Psychiatric reform in the SUS and the struggle for a society without asylums. Ciênc Saúde Colet. 2018;23(6):2067-74. doi: 10.1590/1413-81232018236.07082018

24. Silva PRF, Carvalho MCA, Cavalcanti MT, Echebarrena RC, Mello AS, Dahl CM, et al. Deinstitutionalization of long stay patients in a psychiatric hospital in Rio de Janeiro. Ciênc Saúde Colet. 2017;22(7):2341-52. doi: 10.1590/1413-81232017227.19152015

25. Silva TCR, Campos MM. Gestão de saúde mental em município de pequeno porte no estado do Rio de Janeiro. Vértices. 2015;17(3):35-64. doi: 10.19180/1809-2667.v17n315-02

26. Ministério da Saúde (BR). Secretaria de Atenção à Saúde (SAS). Departamento de Ações Programáticas Estratégicas. Residências terapêuticas: o que são, para que servem [Internet]. Brasília: Ministério da Saúde; 2004 [cited 2018 Mar 21]. Available from: http://bvsms. saude.gov.br/bvs/publicacoes/120.pdf

27. Klein SK, Fofonka A, Hirdes A, Jacob MHVM. Quality of life and levels of physical activity of residents living in therapeutic residential care facilities in Southern Brazil. Ciênc Saúde Colet. 2018;23(5):1521-30. doi: 10.1590/1413-81232018235.13432016

28. Freire VS, Cabral BEB. Saúde mental no território: reflexões sobre agenciamentos possíveis na relação coma residência terapêutica. Cad Bras Saúde Mental [Internet]. 2016 [cited 2018 Aug 11];8(19):17-41. Available from: http://incubadora.periodicos.ufsc.br/index.php/cbsm/article/view/3470

29. Roza Junior JA, Loffredo AM. Residências Terapêuticas e a cidade: enfrentamentos de normas sociais vigentes. Saúde Debate. 2018;42(116):287-95. doi: 10.1590/0103-1104201811623

30. Moll MF. Dos hospitais psiquiátricos aos serviços residenciais terapêuticos: um olhar sobre os direitos humanos neste percurso [Tese]. Ribeirão Preto: Universidade de São Paulo; 2013. doi: 10.11606/T.22.2013.tde-07012014-102039 